\title{
Unraveling the Use of Quantity Maxim among EFL Learners on Online Classroom Interaction
}

\author{
Mercya Christ Sita Dewi ${ }^{{ }^{*}}$, Lilia Indriani ${ }^{2}$ \\ ${ }^{1,2}$ Universitas Tidar, Magelang, Indonesia \\ *Corresponding Author: mercyachrist@gmail.com
}

\begin{abstract}
This naturalistic qualitative study is intended to unravel the working of quantity maxim introduced by Grice (1975) on EFL online classroom interaction amid the Covid-19 pandemic. Besides, this study is designed to investigate whether or not students violating or obeying the quantity maxim by observing and unraveling the utterances produced during online classroom interaction. Moreover, this study also provides factors that influence the non-observance maxim of quantity. The participant consists of 31 students from the fifth semester majoring in English Education at Tidar University. The study is conducted by recording, transcribing, and classifying the conversations done on online classroom interaction, viewed from Gricean maxim perspectives. The results reflect that students both observed and violated the maxim of quantity. The total number of observance maxim is 9 , and 14 for the non-observance maxim. This study brings the conclusion that external factors such as unstable internet connection and interference coming from the surrounding environment during the online classroom can cause EFL students to break the maxim of quantity principle. Meanwhile, anxiety as an internal factor plays a crucial factor that leads the EFL students to violate the quantity maxim.
\end{abstract}

Keywords: EFL classroom interaction, non-observance, observance, quantity maxim

\section{INTRODUCTION}

Classroom interaction is always mediated through a language since language has a significant purpose in delivering people's message and intention. Hidayati et al. (2018) convey that language is used to express someone's feelings, thoughts, and maintain a social relationship. In a social relationship, both speaker and audience should be cooperative and informative. In consequence, an ability to understand and interpret the discourse is an essential element in communication (Dwi, 2015). Understanding the discourse itself can be done by unraveling the utterances produced by the speakers. Schiffrin (1994) notes that utterances comprise the speaker's assumption and intention to the discourse. Following that statement, Grice (1975) purposes cooperative principles to interpret the correlation of the discourse and what speakers uttered. Cooperative principles purposed by Grice also aims to guide the speakers to speak as cooperative as possible to avoid miscommunication. Further, Zhou (2009) highlights that the cooperative principle is a successful example of a theory illustrating how human communication and conversational implications are governed by principles.

In English as a foreign language classroom, this cooperative principle is applied in teaching-learning interaction to attain communication ability and better understanding in responding to a particular question and command. Following Grice's theory, classroom interaction among EFL students should be informative, unambiguous, relevant, true, and 
concise so that the message can be delivered correctly and clear (Widiasri et al., 2019). The cooperative principle introduced by Grice is comprised of four maxims, videlicet the quantity maxim, the quantity maxim, the relation maxim, and the manner maxim.

Quantity maxim commands the speakers to speak properly about what is needed to be answered and not out of the main topic of discussion. Moreover, the answer should be informative, accurate, and not give an extra explanation (Linawati, 2013; Thomas, 1995; Yule, 1996). Meanwhile, the quality maxim only allows the speakers to make precise statements; it means speakers should not speak without evidence. It should not be too much or too little otherwise, this maxim will be violated (Betti \& Yaseen, 2020; Locastro, 2012). The third is a maxim of relation, which claims that the speaker's messages should be matched and related to the topic to achieve good communication (Grice, 1975). Another maxim, the maxim of manner aims to avoid ambiguity and obscurity. Considering the previous principles, the speaker should be aware: clear, brief, and orderly in delivering utterances in communication (Lindblom, 2001; Widiasri et al., 2019). The collaboration of these four principles can be employed to examine the interaction in an EFL classroom.

Gricean maxims in such a way can be observed, flouted, opted-out, infringed, and violated. Observance maxim implies that the speaker understands the context of the topic and able to respond appropriately. In contrast, when the speaker has no intention to mislead the audience, yet the utterance does not directly state to interpret the conversational implicature, it is categorized as a flouting maxim. On the other hand, the speaker will violate the maxim when deliberately misleads the topic, provides incomplete information, and be irrelevant. Meanwhile, opting-out of the maxim may occur when the speaker may be unwilling to contribute and choose not to follow the maxim. Further, an infringing maxim exists as the result of lacking knowledge and inability to speak the target language clearly (Faridah, 2018; Rohaniyah, 2013).

Predominantly, the study about maxim principle concerns with the frequency of observance and non-observance of Gricean maxim principles, major causes that contribute speakers violated maxim, and the importance of integrating maxim principles in EFL classroom interaction. For instance, Dwi (2015) conducted a study about a non-observance maxim that occurred in EFL classroom interaction by analyzing the dialogues during teaching-learning activity. The data revealed that only $2 \%$ of the dialogues flouted the maxim. Hutahean (2020) examined the teaching and learning process in Junior High School. They found out that teachers had habits of adding too much unimportant information to give many lessons, whereas students tended not to provide enough information related to the questions given. In line with the first previous study, Yusro et al. (2020) investigated how teachers and students observed and violated maxim in EFL classroom interaction. They argued that most of the students violated the maxim because they experienced doubt or anxiety and wanted to give extra information to the interlocutor.

Considering the previous studies above current study concerns with quantity maxim and formulates two questions as an objective of the study, as follows: 1) Do students follow the principle of quantity maxim during online classroom interaction? 2) What factors do influence quantity maxim during online classroom interaction?

\section{METHOD}

This study was categorized as qualitative research since the data were gained through observing teaching and learning activity. Qualitative research provides descriptive data from the fact, 
actual words, or actions of people, involving a deep grasp and description of documents or phenomena. Cresswell (2012) points out that the core of qualitative research is laid on the concept, idea, and process observed. In line with the statement, this current research focuses on exploring the working of quantity maxim among EFL students on online classroom interaction, especially in students' presentations. Participant in this study involved 31 students from the fifth semester majoring in English Education at Tidar University.

First, the data were collected naturally by observing students' presentations on the ZOOM meeting and WhatsApp in which the researchers participated in the classroom activity. Gay et al. (2011) explained when the researchers joined the activity of the participants, then, the observation is classified as participant observation. Sugiyono (2012) articulated that observation as one of the methods in collecting the data facilitated the researcher to learn and examine the meaning attached to behaviors produced by participants. Second, the data were collected by taking notes and recording the utterance. Further, the utterances produced by participants were also transcribed.

Three steps were done in order to analyze the data as follows: 1) Classifying the conversation or utterances, which were categorized as a maxim of quantity. 2) Determining the utterances that observed and floated the maxim of quantity principle. 3) Unraveling what causes contributed to violating maxim of quantity among EFL students on online classroom interaction.

\section{FINDINGS AND DISCUSSION}

The current study was devoted to investigating the use of Gricean quantity maxim, particularly on online classroom interaction and factors that influence students to observe and violate quantity maxim principles. The finding of the study was supported by previous literature (Abdelhafez, 2016; Adebola, 2018; Betti \& Yaseen, 2020; Faridah, 2018; Hidayati \& Lukman, Lukman; Azmi, 2018), which mainly concerned with the analysis of Gricean maxim principles in the EFL classroom interaction.

Table 1. The Distribution of Quantity Maxim in Each Conversation

\begin{tabular}{cccc}
\hline \multirow{2}{*}{ Conversation } & \multicolumn{2}{c}{ Maxim of Quantity } & Total \\
\hline 1 & Observance & Non-Observance & 1 \\
2 & 1 & 1 & 1 \\
3 & 1 & & 1 \\
4 & 1 & & 1 \\
5 & 1 & 1 & 1 \\
6 & 1 & 1 & 1 \\
7 & & 1 & 1 \\
8 & & 1 & 1 \\
9 & & 2 & 1 \\
10 & & 1 & 2 \\
11 & 1 & 3 & 2 \\
12 & 1 & 3 & 4 \\
13 & 2 & 14 & 5 \\
14 & 9 & 23 \\
Total & 9 & & \\
\hline
\end{tabular}


Detail explanations of the use of quantity maxim to promote classroom presentation among EFL students on online classroom were unraveled in the following extracts of each conversation. The study identified that fourteen times students violated maxim quantity and nine times students obeyed the maxim. The distribution of quantity maxim could be noticed in the Table 1.

The analysis of each conversation was displayed in the following extracts, in which ' $\mathrm{P}$ ' is employed as a presenter and ' $\mathrm{A}$ ' as an audience.

\section{Conversation 1: Greeting \\ P: $\quad$ Good morning \\ A(s): Morning}

In the first conversation, all of the audience observe the quantity maxim, in which they replied to the presenter's greeting properly.

Conversation 2: Asking and giving clarification

P: Udah kelihatan belum? (Have you seen?)

\section{A: Masih proses (It is still loading)}

Conversation 2 indicates that audience flouted the quantity maxim since the audience had no intention to mislead the presenter. The extract above is categorized as non-observance maxim of quantity because the audience did not provide clear information. The audience should respond whether they could see the presentation slide or not, yet they replied that the slide was still loading.

Conversation 3: Asking and giving clarification

P: $\quad$ Could you hear my voice?

$\mathrm{A}(\mathrm{s})$ : Yes, I can

In responding to the presenter's question, the audience has given informative clarification. Thus, in conversation 3 the audiences follow the principle of quantity maxim.

Conversation 4: Asking and giving clarification

P: $\quad$ Could you understand?

A(s): Yes

A(s): Yes, I got it

Similar to conversation 3 , in this extract the audiences respond to the presenter's question appropriately by observing the knowledge of maxim of quantity.

Conversation 5: Asking and giving clarification

P: $\quad$ Could you get the point?

$\mathrm{A}(\mathrm{s})$ : Yes, I got it

Conversation 5 conveys that the audiences obeyed the maxim of quantity. Similar to conversation 4 , the audiences gave a clear clarification or answer.

Conversation 6: Asking a question

P: $\quad$ Do you have any problem

A(s): (no answer)

In conversation 6 , the audience opt-out of the quantity maxim since none was unwilling to contribute and choose not to follow the maxim. This phenomenon often occurs in the context 
of EFL classroom interaction. Brown (2007) mentions that not get involved in classroom interaction has become a general stereotype of EFL students in Asia. Thus, conversation 6 is evidence of Brown's theory that leads to a non-observance maxim of quantity.

Conversation 7: Asking and giving clarification

P: $\quad$ Is it my voice clearly?

A: $\quad$ Yes

The presenter and audience were straight to the point when asking and giving clarification. Following that fact, the expression in conversation 7 fulfills the quantity maxim.

\section{Conversation 8: Giving clarification \\ P: $\quad$ Okay Lina this is your chance to present the material \\ P2: (no answer)}

Conversation 8 violates the quantity maxim theory since the second speaker did not give any response to the clarification of the previous presenter. In this online classroom interaction, the researchers assumed that the second presenter did not pay attention to the first presenter since she did not reply to anything. This could be the lack of concentration or unstable signal since the meeting was held by using the ZOOM meeting.

\section{Conversation 9: Asking and giving clarification \\ P: Can you hear my voice?}

$\mathrm{A}(\mathrm{s})$ : Yes, but the slide is freeze

Conversation 9 clearly indicates that the audience violated the quantity maxim since the audience provided more information that was required. The presenter asked whether the audience could hear her voice clearly or not, yet in responding to the question the audience added information that the slide presentation did not run.

Conversation 10: Asking and giving clarification

P: $\quad$ Okay, you got the point?

A: (no answer)

The phenomenon of conversation 6 occurred in conversation 10 in which no audiences responded to the presenter's question. Thus, conversation 10 is labeled as a maxim quantity that opted-out or did not obey principle.

Conversation 11: Inviting and asking a question

P: $\quad$ Okay, we will open the question and answer season for three person. Let's start our discussion

A: $\quad$ Assalamu Alaikum Warahmatullahi Wabarakatuh. I'm Ghina Fauzia Rafida, first of all, I'm going to say thank you for Pradita Lina and the group for today's presentation and I wanna ask some questions relating to today's material that. Could you please explain the differences between pidgins and creole in a simple way, maybe you can use Bahasa to make it more clear, thank you.

A2: $\quad$ So here, I am Mercya and I'd like to try to answer your question, Ghina. First, what is the difference between pidgin and creole? At the first one is about the users, so pidgin is used for those who is non-native speaker, while creole mostly used by native um... speaker. So, it is a native speaker exists. And the second one, in pidgin, pidgin is mixing of language while creole is a mixed language associated with cultures and often racial mixer. So, pidgin is just umm... the mixing of language, while creole there is a 
culture that is associated with that language. And the last one in pidgin, mostly it reduce grammar and vocabulary, while creole it is hmm, you that creole is actually based on pidgin, so once we have a parent who is pidgin, mostly they will produce creole. That's it about my explanation. Thank you.

A: Thank you

The conversation above demonstrates that the audiences violated the quantity maxim. The expression, "...first of all, I'm going to say thank you for Pradita Lina and the group for today's presentation..." was not required in asking a question. The audience only requested to mention the name, purpose, and the question. In addition, the second audience in order to respond to the question provided extra information than was expected. The first audience expected to know the simple differences between pidgins and creole, yet the second audience gave more than a sufficient amount of information even repetition that was not needed.

Conversation 12: Asking question and giving answer

A: I am Sekar Lathifatul Aliyah. I would like to ask about pidgin. Is there any impact to the native language for particular group after the pidgin has been created between the two groups of people? Thank you

A2: Here I'm Kenti Sugiyati would like to try to answer Sekar's question. Is there any impact to the native language for particular group after the pidgin has been created between the two groups of people? So, I would like to say yes because as we know that pidgin is referred to the uniqueness of the language used, created by the culture where the pidgin is created. The pidgin emerges the language to create uh... new system both in phonological, morphological, and syntax, so that it is influence uh... the use of the native language. for example English so that there is a new terms of the use of English for example in vocabulary and also $\mathrm{hmm}$ it will influence umm... the communication breakdowns because the new system that created by each pidgin for the each culture. I think that all about my answer. Thank you.

A: $\quad$ Yes, I got the point. Thank you, Kenti.

In asking a question, the first audience has already observed the principle of quantity maxim since she was straight to the point of the question. However, the second audience flouted the maxim of quantity in delivering an explanation. The expression, "for example English so that there is a new term of the use of English for example in vocabulary and also $\mathrm{hmm}$ it will influence umm... the communication breakdowns because the new system created by each pidgin for each culture" was more than required. The explanation only needed to point out the impact of pidgin in a certain group, but the second audience explained anything at length. This phenomenon may occur due to the EFL student has sufficient or more knowledge about the material.

Conversation 13: Asking question and giving answer

A: Good morning and thank you for the excellent presentation. Here, I am Kenti Sugiyati want to ask relates to the presentation. Is it possible to Indonesia for having English pidgin or creole, considering Indonesia which has hundreds languages and cultures also considering the English as foreign language. Thank you.

P: $\quad$ Yes, it is possible. As we know, Indonesia has many variations of language. It can be a pidgin because pidgin is results from extended contact between groups of people with more than two different language. 
A2: Look what I got (send a screenshot about the existence of Indonesian Language Pidgin or Creole).

A: $\quad$ So based on the study it can be said that Indonesian cannot be categorized as pidgin and creole. Does this context refer to Bahasa Indonesia?

P: $\quad$ Oh... I see, but I think it is possible if maybe the next few years Indonesia have an English pidgin. What about you, Mer?

A2: Yes, Kenti (A). I'm sorry since I've not got any data about pidginization and creolization in Indonesian-English language

A: That's okay Mercya! I still can obtain such worth knowledge related to pidgin and creole in Indonesian context.

In conversation 13, the audience and presenter both complied and flouted the quantity maxim. First, in delivering a question the first audience was not straight to the point. The utterance, "thank you for the excellent presentation" indicated that the first audience flouted the maxim since it was not needed in asking a question. Despite that, the presenter could catch the meaning and provided amount sufficient contribution to respond to the question. Meanwhile, the second audience was accidentally infringed on the quantity maxim by presenting irrelevant information that was out of the topic. The utterance, "Look what I got (send a screenshot about the existence of Indonesian Language Pidgin or Creole)", illustrated that This phenomenon might occur in the EFL context due to the lack of concentration or awareness of English, some EFL students commonly misinterpret the utterance because of the lack of exposure in English. The second audience also unintentionally neglected the presenter's question in this expression, "What about you, Mer?" the second audience neither answered nor responded to the question.

Conversation 14: Asking question and giving answer

A: $\quad$ Assalamu Alaikum Warahmatullahi Wabarakatuh. I'm Zainika Annisa Nur Rahma. I'd like to ask related to the material today. Hmm, my question is can pidgin or creole replaces the existing of mother tongue? Thank you.

P: $\quad$ Okay, I would like to answer your question. Actually, creole or pidgin is the language that can be the mother tongue. For example in Papua New Guinea, there is the mother tongue called Tok Pisin that developed from creole. That language founded based on the mixing of English and Papua language and some the other Austronesia. So, the children in there acquire that language as their mother tongue.

A2: I'm Rara Zahrathira Mahardika and I would try to answer Zainika's question. In my opinion, pid... pidgin or creole is cannot replace the mother tongue since the existence of pidgin and creole is when $\mathbf{h m m}$... there are many... there are many different language and no language dominant other. But ah... we know creole is a pidgin that hmm create a new one, so in my opinion it cannot replace the mother tongue, but it can create a new language itself. Thank you.

A3: In my opinion, yes. It can be replaced the existence of mother tongue since it would be frequently used. It happens when in the situation which there is imbalance of power among the language as the speakers of one language control the speakers of the other language economically and socially. And when dealing with other groups, the speakers adopt many of these changed to make themselves more readily understood and no longer try to speak as they do within their own group. So, it slowly can be replaced the existence of mother tongue. 
A4: In my point of view pidgin and creole can't replace the existence of our mother tongue because actually our mother tongue can't replace with the other language. I mean we can learn or we can get various languages but our mother tongue can't be lost from us although we use our new languages frequently we still remember with our mother tongue. Sorry if there any mistakes.

Conversation 14 above demonstrates that most of the audiences violated the quantity maxim principle by delivering insufficient explanation, which was not directly to the point. The answer that was required was a brief explanation on whether pidgin or creole could replace the existence of mother tongue or not. However, all of the audiences either unintentionally or intentionally stated more than was required in responding to the question by giving an example, repetition, and unrelated explanation. In line with the repetition phenomenon in stating the argument, Hardianti (2016) highlights that repetition that reveals in the use of fillers or hesitation devices are common habits, which mainly occurs because of hesitation and anxiety among non-native students in speaking English.

The results above demonstrate how EFL students both neglected and observed the quantity maxim in doing interaction. By looking at those interactions, the study identifies five types of interaction that mostly occurred in the ELT context among EFL students as follows: greeting; giving clarification during the presentation; asking, inviting, and answering questions. This view supports Sukriawati's (2019) study about Gricean maxim in EFL classroom interaction. She revealed that those five interactions always happen in the EFL classroom since the basic interaction in the language classroom is turn-taking interaction between teacher and students. Further, the results above also uncover the factors behind the non-observance maxim of quantity.

In the context of online interaction, several factors can influence non-native students to violate the quantity maxim. Those factors are anxiety, being too informative, and lack of focus. Foreign language students commonly experience anxiety. Horwitz (2001) states that this phenomenon occurs from the immature non-native speakers. In their study, Koch and Terrell (1991) claim that oral presentation becomes one of the activities that provoke anxiety. In accordance with the finding, this anxiety phenomenon can be found in conversation 14 .

In the EFL context, anxiety emerges as a result of the lack of knowledge in the target language, fear of negative evaluations, and fear of making mistakes (Horwitz, 2001). This view supports Ahmed's (2016) study about conversational implicatures in EFL students. He states that awareness of negative evaluation leads EFL students to flout the Gricean maxim principle. It is proven in conversation 14, "Sorry if there any mistakes." It can be noticed that EFL students tend to be afraid of negative evaluations once they make a mistake. In consequence, this expression leads students to violate the quantity maxim since it is not required in responding to the question.

Another factor that is being too informative can cause EFL students to disobey the quantity maxim. It is due to the notion of quantity maxim is to give the speaker's contribution as informative as required (Grice, 1975). The violating maxim of quantity arises because the speaker is willing to provide more information to the interlocutor. In this case, the speaker wants to make the interlocutor grasps the speaker's explanation.

Despite internal factors, some external factors also influence students to violate the quantity maxim. Since this study is taken place in an online classroom during the Covid-19 pandemic, the major factors are unstable internet connection and interference coming from the surrounding environment. It is supported by Nartiningrum \& Nugroho study (2020), they conducted a study about challenges faced during online learning amidst pandemic. They 
mentioned that the main challenge in attending an online classroom was an unsteady internet connection, and it brought an impact on students' respond and understanding. The evidence can found in conversation 8 , in which the second presenter needs a moment to answer the first presenter's instruction.

\section{CONCLUSION}

Unraveling the working of quantity maxim introduced by Grice (1975) becomes the focal point of this current study. According to the results, the role of quantity maxim among EFL students could not be neglected, even in online classroom interaction. The results display that the maxim of quantity has been violated fourteen times and obeyed nine times during the classroom interaction in the EFL context. This study identifies several factors that cause EFL students to disobey the maxim of quantity principles such as anxiety and fear of making mistakes or negative evaluations. Besides, the study also notices that external factors such as unstable internet connection and distractions coming from the surrounding environment during the online classroom amid the Covid-19 pandemic can contribute the EFL students to violate the quantity maxim.

\section{REFERENCES}

Abdelhafez, A. M. M. (2016). The Effect of Conversational Implicature Instruction on Developing TEFL Students' Pragmatic Competence and Language Proficiency. USChina Education Review A, 6(8), 451-465. https://doi.org/10.17265/2161$623 \mathrm{x} / 2016.08 .001$

Adebola, O. A. (2018). Cooperative Principle Maxims In Whatsapp Conversations Among Undergraduates In The Federal University Of Technology Akure, Ondo State, Nigeria. Advances in Social Sciences Research Journal, 5(10), 542-557. https://doi.org/10.14738/assrj.510.5309

Betti, M. J., \& Yaseen, K. S. (2020). The Iraqi EFL Learners' Use of Conversational Maxims at the University Level. Education, Language and Sociology Research, 1(1), 43-60. https://doi.org/10.22158/elsr.v1n1p43

Brown, H. D. (2007). Priciples of Language Learning and Teaching (Fifth Edit). Pearson Education, Inc.

Creswell, J. (2012). Educational Research. 4th Edition. Pearson Education, Inc.

Dwi E.S., A. (2015). An Analysis of Flouting Maxim in EFL Classroom Interaction. Journal Vision, 4(2), 243-259.

Faridah, H. N. (2018). A Descriptive Analysis of Maxims of Cooperative Principle in the Teacher-Students Interaction in English Teaching and Learning Process in SMK Batik I Surakarta Academic Year 2017/2018.

Gay, L.R.; Mills, G., \& E.; Airasian, P. w. (2011). Educational Research. PEARSON.

Grice, H. P. (1975). Logic and conversation. ACADEMIC PRESS, INC.

Hardianti, R. (2016). A study of efl students' oral communication strategies in discussions. Indonesian EFL Journal, 2(1), 23-33.

Hidayati, H., \& Lukman, Lukman; Azmi, M. U. (2018). A Conversational Analysis of Grice's Maxims Theories on Cooperative Principles at Undergraduate English Students. Journal of English Language Teaching and Linguistics (JELTL), 11(1), 5. https://doi.org/10.31764/leltj.v11i1.742

Horwitz, E. (2001). Language anxiety and achievement. Annual Review of Applied Linguistics, 
21, 112-126. https://doi.org/10.1017/s0267190501000071

Hutahaean, D. T. P. C. N. H. (2020). The Cooperative Principle in Conversation. Wiralodra English Journal (WEJ), 4(1), 82-96. https://www.thoughtco.com/cooperative-principleconversation-1689928

Koch, Susan, and 'Racy 'knell. (1991). The Effect ofthe Natural Approach on the Affective Filter. Prentice Hall, in press.

Linawati, D. (2013). A Gricean Maxim Analysis Of An English Teacher 'S Talks in SMP N 1 Kalasan ( A Case Study). Universitas Yogyakarta.

Lindblom, K. (2001). Cooperating with Grice: A cross-disciplinary metaperspective on uses of Grice's cooperative principle. Journal of Pragmatics, 33(10), 1601-1623. https://doi.org/10.1016/S0378- 2166(00)00069-2

Locastro, V. (2012). Pragmatics for Language Educators: A Sociolinguistic Perspective. Routledge Taylor \& Francis Group. https://doi.org/10.4324/9780203850947

Nartiningrum, Novrika;Nugroho, A. (2020). Online Learning amidst Global Pandemic : EFL Students' Challenges, Suggestions, and Needed Materials. ENGLISH FRANCA: Academic Journal of English Language and Education, 4(2), 115-140.

Rohaniyah, J. (2013). Socio-Pragmatic Study; The Obscurity of Gricean Maxims ( Cooperative Principle Rules) [The Study of Flouted Maxims in Conversation through Gender Categories]. OKARA, 2, 1-14.

Safitri, Mega L; Seken, K., \& Putra, A. J. N. (2014). Observance and Non-Observance of Gricean Maxims in Instructional Context: an Analysis of Efl Classroom Interaction. Jurnal Pendidikan Bahasa Inggris, 2(1).

Schiffrin, D. (1994). Approaches to Discourse. Blackwell Publishers. Taguchi,.

Sugiyono. (2012). Metode penelitian Kuantitatif, Kualitatif, dan Kombinasi (mixed methods). Penerbit Alfabeta. 14.

Sukriawati. (2019). A Gricean Maxim Analysis in EFL Classroom Interaction [Universitas Negeri Makassar]. http://eprints.unm.ac.id/15203/1/ARTICLE JOURNAL.pdf

Thomas, J. (1995). Meaning In Interaction; An Introduction to Pragmatics. Longman.

Widiasri, D. A., Budiarsa, M., Sudipa, N., \& Satyawati, M. S. (2019). Cooperative Principle Implementation between Teachers and Students : Indonesian Language Teaching Case. International Journal of Social Sciences and Humanities, 3(2), 302-308.

Yule, G. (1996). Pragmatics. Oxford University Press.

Yusro, A., Sutopo, D., \& Yuliasri, I. (2020). The Application of Cooperative Principles in EFL Classroom Interaction: The Case of SMAN 4 Pekalongan. English Education Journal, $10(2), 124-130$.

Zhou, M. (2009). Cooperative Principle in Oral English Teaching. International Education Studies, 2(3), 42-46. 